Postprint.

For published article see:

Yao, R., \& Cheng, G. (2017). Millennials' Retirement Saving Behavior: Account Ownership and Balance. Family and Consumer Sciences Research Journal, 46(2), 110-128. https://doi.org/10.1111/fcsr.12241

\title{
Millennials' Retirement Saving Behavior: Account Ownership and Balance
}

\begin{abstract}
Millennials is the largest population in the United States. Compared with their parents and grandparents, they have to shoulder more responsibilities to prepare financially for retirement. It is critical for Millennials to begin saving and investing for their retirements early in their careers. Few studies analyzed this generation's retirement saving behavior. Using data from the 2013 Survey of Consumer Finances, this study is among the first ones to examine the state of Millennials' retirement savings, including retirement account ownership and balance. Results show that only $37.2 \%$ of Millennials had any kind of account earmarked for retirement; and among those with a retirement account, the average accumulated amount was $\$ 21,333$. Factors that affected retirement saving behavior included age; education; total household income and assets; job tenure; self-employment; having a retirement saving motive; having a defined benefit plan; overspending; and risk tolerance. This study provided initial insights that can help financial planners and educators, as well as policymakers understand Millennials' current retirement savings behavior and help them achieve a financially comfortable retirement.
\end{abstract}

Key words: Defined Contribution plan, IRA, Millennial, Retirement, Saving 


\section{Introduction}

Millennials, those born between 1982 and 2000 (U.S. Census Bureau, 2015), accounted for more than $25 \%$ of the U.S. population in 2015 , and as the nation's largest generation, they outnumbered Baby Boomers by approximately 0.5 million in 2016 (Fry, 2016). There may appear to be sufficient time for these 83.1 million individuals to save for retirement. However, unlike their parents and grandparents, Millennials have to shoulder more responsibilities to prepare financially for retirement. For example, the number of pension plans available for private sector employees has declined in recent decades (Boivie, 2011) as employers transition to offering defined contribution (DC) plans versus defined benefit (DB) plans (US Department of Labor, 2016). In 1998, more than half (292) of the Fortune 500 firms offered DB plans; however, in 2015, only 99 firms still did so (Geisel, 2016). With DC plans, Millennial participants face potential investment risks and uncertain plan funding decisions, and lack investment expertise as well. All of these changes have made it more difficult for them to save for retirement. In addition, future payouts on the part of Social Security have become uncertain (Social Security Board of Trustees, 2017), as Baby Boomers in particular have begun to withdraw from the system (Oakley \& Kenneally, 2013). Thus, the Social Security Trust Fund will be reduced severely, and may be depleted completely in 2034 (Social Security Board of Trustees, 2017). As a result, the financial outlook for retirement in today's workforce is a concern.

In addition to the shift in financial responsibilities, the increasing longevity and current low interest rate economic environment has made it more challenging for Millennials to prepare for retirement (Genay \& Podjasek, 2014). The life expectancy in the U.S. has increased substantially in the past century from 54.5 in 1915 to 78.8 in 2015 (National Center for Health Statistics, 2017). Although retirement was not a financial concern until just a few decades ago, 
with the increasing life expectancy, it has become very important now. In addition, the expected return on fixed-income investments in any retirement portfolio is low in the current economic environment, in which both short-term and long-term interest rates are low (Bams, Schotman, \& Tyagi, 2016). Thus, those who do not have sufficient money saved for retirement are unlikely to be able to maintain a financially comfortable life during retirement.

A large proportion of American workers do not save enough for retirement. Munnell, Webb, and Hou (2014) reported that more than half of working-age Americans had not saved enough to be able to maintain their pre-retirement standard of living during retirement. More than half (52\%) of individuals aged 55 and older in the U.S. do not have retirement savings in DC plan accounts or IRAs. In addition, half (50\%) of individuals aged 65 and older rely on Social Security as their primary source of retirement income (Jeszeck, Collins, Glickman, Hoffrey, \& Grover, 2015).

Given the conditions above, it is critical for Millennials to begin saving and investing for their retirements early in their careers. As DC plans become a more important source of retirement income, the burden of securing an adequate standard of living in retirement has shifted to individuals. Unlike DB plan participants, individuals who are eligible to participate in a DC plan face important decisions, including whether and to what degree to participate. Opening a retirement account is the first step in saving for retirement. More importantly, the amount accumulated in the account is a key factor in realizing adequate retirement savings. Because of the power of compounding on investment returns, DC plan balances can be reduced considerably by only a small decrease in regular contributions (Yao, Ying, \& Micheas, 2013) and jeopardize one's retirement savings goals. Thus, strategic and disciplined savings and investments have become more important than ever. 
Although many prior studies have analyzed the retirement savings behavior of the Baby Boomer generation, very few have focused on Millennials' retirement preparation. Using the 2013 Survey of Consumer Finances (SCF) dataset, this study analyzed Millennials' ownership of, and asset balances in accounts earmarked for retirement purposes, such as Individual Retirement Accounts (IRAs) and DC plans. Factors that contributed to account ownership and account balances were examined as well. The findings will help financial planners, educators, and policymakers understand Millennials' current retirement savings behavior, which is the first step in helping them build adequate retirement wealth.

\section{Literature Review}

Few prior studies, with the exception of several surveys conducted by financial institutions have examined factors that affect Millennials' retirement savings. The industry reports agreed that a significant proportion of Millennials are not saving for retirement. According to the Pentegra Millennial Saving Survey (Pentegra Retirement Services, 2017), only $37 \%$ of the respondents born between 1980 and 2000 saved at least $5 \%$ of their salary for retirement. The reason for this savings inadequacy was due to the increasing cost of living and debt payments, which reduced the amount of money available for retirement planning. The 2016 Wells Fargo Millennial Study (Wells Fargo, 2016) found that 41\% of the 1,000 working respondents (including working full time and part time) aged between 22 and 35 had not yet started saving for retirement. The reason was again the debt payments. This study also concluded that low income was one of the main reasons for not saving for retirement. Low income females had even more difficulties to save for retirement than their male counterparts. The 2016 Fidelity Investments Millennial Money Study (Fidelity Investments, 2016) reported that among the 615 adults in the study, including 305 respondents aged between 25 and 35, 47\% received financial 
support from their parents; however, more than half $(60 \%)$ had started putting money into retirement accounts. Although these results are descriptive in nature, they provide a general picture of Millennials' current retirement savings situation.

Few academic studies have examined Millennials' financial status, especially pertaining to their retirement savings. However, a review of literature that investigates factors that affect retirement savings for all age groups provided valuable insights for this study.

\section{Retirement Account Ownership}

\section{Demographic Characteristics}

Age has been a common variable examined in previous studies of retirement savings. The percentage of retirement account ownership was low among young adults. For example, only $20 \%$ of adults between the ages of 22 and 35 had IRAs and less than $40 \%$ had a DC plan (Knoll, Tamborini, \& Whitman, 2012). Researchers agree that young people generally have a lower participation rate in retirement accounts than older adults (Bassett, Fleming, \& Rodrigues, 1998; Hira, Rock, \& Loibl, 2009; Honig \& Dushi, 2010). For example, older respondents were found to be more likely to have DC plans and IRAs than young respondents (DeVaney \& Zhang, 2001). After analyzing the 2008 Survey of Income and Program Participation, Ghilarducci, SaadLessler, and Bahn (2015) found that $42 \%$ of individuals aged 25 to 44 had a DC plan, compared to $47 \%$ of those aged 45 to 54 .

Race/ethnicity also has been examined commonly in previous research on retirement account ownership. Empirical evidence has shown that White employees were more likely to have access to, and participate in retirement accounts than employees of color (Farrell \& Shoag, 2016; Knoll et al., 2012; Rhee, 2013; Yuh \& DeVaney, 1996). According to Rhee (2013), 62\% of White employees had a retirement account, compared to only $54 \%$ of Black and $38 \%$ of 
Latino employees. Results from Ghilarducci et al. (2015) showed that $48 \%$ of White households had DC plans compared to $44 \%$ of Asian, $41 \%$ of Black, and $28 \%$ of Hispanic households. In addition, 30.8\% of Latino households had no retirement account assets (Rhee, 2013).

Compared to men, women are less likely to have retirement accounts (Sunden \& Surette, 1998; Bajtelsmit, Bernasek, \& Jianakoplos, 1999; Lusardi \& Mitchell, 2007; Holden \& Fontes, 2009). Hinz, McCarthy, and Turner (1997) found that the percentage of women with a retirement Thrift Savings Plan was much smaller than that of men. Many previous researchers explained that this likely is attributable to the fact that women more often have part-time and lower-paying jobs than men and, therefore, limited access to employer-sponsored retirement plans (Knoll et al., 2012).

Marital status was found to be closely related to retirement account ownership as well. Researchers have demonstrated that married households were more likely to have retirement accounts, including DC plans and IRAs (DeVaney \& Zhang, 2001; Knoll et al., 2012; Lusardi \& Mitchell, 2007). Evidence also has shown a positive relationship between education and retirement plan ownership (Carney \& Gale, 2001; Hira et al., 2009; Lusardi \& Mitchell, 2007; Yuh \& DeVaney, 1996). For example, individuals with a bachelor's degree or higher were more likely to have DC plans than were those with an associate's degree (Farrell \& Shoag, 2016). Employment (Hire et al., 2009) and job tenure (Bassett et al., 1998) have been shown to be positively correlated with retirement account ownership, including 401(k)s, IRAs, and Keogh accounts. Yuh and DeVaney (1996) found that self-employed workers were less likely to have and contribute to retirement accounts, as only $30.4 \%$ of such workers had retirement accounts compared to $44.4 \%$ of workers with other employment status.

\section{Economic Status}


Income is related positively to retirement account ownership. For example, $32.4 \%$ of individuals with incomes less than $\$ 30,000$ had IRAs, compared to $47.2 \%$ of those with incomes between $\$ 50,000$ and $\$ 100,000$. In addition, $45.4 \%$ of people with incomes less than $\$ 30,000$ had DC plans compared to $49.2 \%$ of those with incomes between $\$ 50,000$ and $\$ 100,000$ (Poterba \& Wise, 1998). According to Ghilarducci et al. (2015), only $25 \%$ of low-income households had DC plans compared to $48 \%$ of middle-income households and $60 \%$ of high-income households. Low-income households also were less likely to save for retirement (Burke, Hung, \& Luoto, 2015; Hershey, Jacobs-Lawson, McArdle, \& Hamagami, 2007; Hira et al., 2009; Lusardi \& Mitchell, 2007). Empirical results have shown that individuals with higher net worth were more likely to have Roth IRAs (Smith, Finke, \& Huston, 2012).

Consulting with a financial planner when making saving and investment decisions was positively related to having a retirement account (Clark, d'Ambrosio, McDermed, \& Sawant, 2003). It is likely that financial planners provide beneficial advice and improve clients' understanding of the importance of having retirement accounts (Van Rooij, Lusardi, \& Alessie, 2011). According to Clark et al. (2003), the majority of their participants changed their savings behavior and either opened or contributed to retirement accounts after consulting with financial professionals. Home ownership, having a retirement saving motive, and longer job tenure influence retirement account ownership positively, in that research has found that homeowners were more likely to save for retirement (Xiao \& Noring, 1994) and have retirement accounts (Bassett et al., 1998; Yuh \& DeVaney, 1996). For example, 46.6\% of homeowners had DC plans compared to only $27.1 \%$ of non-homeowners (Yuh \& DeVaney, 1996). Individuals with longer job tenure also were more likely to have DC plans than those with shorter job tenure (Burke et al., 2015). Rhee (2013) found that $74 \%$ of White households that had DB plans also had an IRA 
account or a DC plan. Among White households that did not have a DB plan, $66 \%$ had an IRA account or a DC plan. Retirement account ownership of non-White households followed the same pattern. Similarly, Yuh and DeVaney (1996) concluded that owning a DB plan had a positive effect on retirement account ownership after other factors were controlled. Further, households that did not overspend were more likely to own retirement accounts than those that spent more than or equal their incomes (DeVaney \& Chiremba, 2005).

Respondents' Expectations

Having a retirement saving motive contributed positively to the likelihood of having a 401(k) plan (Xiao, 1997). Poor health status was found to prevent people from contributing to retirement accounts because high medical expenditures reduced their ability to save (Yilmazer \& Scharff, 2014). Results from Yuh and DeVaney's (1996) study showed that individuals with excellent health and a higher risk tolerance were more likely to have DC plans. For example, $31.0 \%$ of respondents who were unwilling to take any financial risks had a DC plan, while $47.9 \%$ of those with some risk tolerance had such plans.

\section{Retirement Account Balance}

\section{Demographic Characteristics}

Evidence from an analysis of the 2013 Employee Benefit Research Institute's retirement database showed that older individuals had much higher average IRA balances than younger people (Copeland, 2015). The 65-74 age group had the largest amount of money saved in their IRA accounts and DC plans compared to those aged 45 to 54 and 55 to 64 (Rhee, 2013; Poterba, 2014). Minority households were found to be less likely than Whites to contribute to retirement plans (Hira et al., 2009). Compared to $37 \%$ of White households, approximately $62 \%$ of Black and $69 \%$ of Latino household held no assets in a retirement account. Black and Hispanic 
households had significantly smaller amounts of retirement account savings than White households (Rhee, 2013). Further, on average, Whites saved three times more in their 401(k) accounts $(\$ 120,000)$ than minority households $(\$ 30,000)$.

Empirical evidence has shown that, on average, men have higher balances in their IRA accounts than women. After controlling for age and other factors, male respondents still had higher IRA account balances than females among all age groups from under 25 to over 70 (Copeland, 2015). According to Bajtelsmit et al. (1999), women tended to have smaller percentages of their wealth (27\%) allocated in DC plans than men (35\%). Previous research results were inconsistent regarding the effect of marital status on retirement account balance. Clark et al. (2006) concluded that married households were more likely to allocate more money to their DC plans than unmarried households. However, Bajtelsmit et al. (1999) obtained evidence that single males allocated more of their wealth to DC plans than married male respondents. In contrast, the same study also found that single females allocated a significantly smaller amount of their wealth to DC plans than married females.

Education was found to be related positively to retirement plan balances (Yuh \& DeVaney, 1996), in that respondents with more education had more money saved in their IRAs (Poterba, Rauh, Venti, \& Wise, 2006). According to Poterba et al. (2006), respondents who earned college or post-graduate degrees had, on average, saved four times as much in their IRAs $(\$ 81,700)$ than those with a high school degree $(\$ 20,400)$. Self-employment also was related negatively to retirement account balances (Yuh \& DeVaney, 1996).

\section{Economic Status}

Prior research has concluded that, when job tenure was controlled, DC account balances were positively related to income (Burke, et al., 2015). For those who had 10 to 20 years of job 
tenure, individuals with an income between $\$ 80,000$ and $\$ 90,000$ had $25 \%$ more in their $401(\mathrm{k})$ accounts than those with incomes between \$40,000 and \$50,000 (Holden \& VanDerhei, 2003). DeVaney and Chiremba (2005) concluded that homeowners saved more money in retirement accounts than renters.

According to Yuh and DeVaney (1996), ownership of DB plans was correlated negatively with DC plan account balances. For instance, those who had a DB plan saved more than $\$ 20,000$ less in their DC plans than those who did not have a DB plan. Job tenure was related positively to 401(k) account balances (VanDerhei, Holden, Alonso \& Copeland, 2008; Yuh \& DeVaney, 1996). For example, among individuals in their 60s, 49\% of those with greater than 30 years of service had saved over $\$ 100,000$ in their $401(\mathrm{k})$ account, while this percentage was $13 \%$ for those who had fewer than 10 years of service (VanDerhei et al., 2008).

Overspending had a negative influence on retirement savings. Households that did not overspend had more money saved in retirement accounts than those who spent more than or equal their incomes (DeVaney \& Chiremba, 2005).

\section{Respondents' Expectations}

Risk tolerance was found to affect DC plan contributions. Risk-averse investors accumulated less money in their retirement accounts (Neelakantan \& Chang, 2010). Yuh and DeVaney’s (1996) results showed that respondents who were unwilling to take any financial risks had only $\$ 5,895$ in retirement savings, compared to $\$ 22,415$ on the part of those with some risk tolerance. Receiving an inheritance increased the probability of having a higher balance in retirement accounts (Lusardi, 2003), and individuals in good health accumulated significantly more money in their 401(k) plans than those in fair or poor health (Burke et al., 2015).

\section{Methodology}




\section{Data}

This study used the dataset from the most recent 2013 SCF. The SCF is a cross-sectional survey conducted triennially and sponsored by the Board of Governors of the Federal Reserve System with support from the Statistics of Income Division of the Internal Revenue Service. The survey provides detailed information on households' demographic characteristics and financial situations, including information from their balance sheets.

The total sample size of the 2013 SCF public data is 6,015 households. Among married/partnered households, the SCF defined the head of the household to be the male in a mix-sex-couple household and the older person in a same-sex-couple household. In a household where the respondent was not the head, all data for the couple are switched. In this study, the couples involved are switched back in order to match the respondent and his/her responses. Among the 6,015 respondents, 986 are Millennials. With very rare exceptions, employees need to be at least 21 years old and complete one year of service with their current employer before they become eligible to contribute to a DC plan and individuals are eligible to contribute to their IRA accounts only if they have taxable compensation. Consequently, respondents who were not working currently were excluded from this study, which resulted in a sample size of 782.

\section{Dependent Variables}

Dependent variables in this study included retirement account ownership and account balances. Those two dependent variables were employed in a Heckman two-step model. In the first step, retirement account ownership was coded 1 if the respondent had a DC and/or an IRA account and 0 if the respondent had neither account. In this study, IRA accounts included traditional IRAs, Roth IRAs, and roll-over IRAs. DC plans included Keogh; 401(k); 403(b); Thrift savings; 457; profit sharing; deferred-compensation; Simplified Employee Pension, and 
Savings Incentive Match Plan for Employees, as well as money purchase and stock purchase plans. In the second step, the retirement account balance was defined as the sum of the balances in IRA accounts and DC plans. This variable is log-transformed due to its right skewness.

\section{Independent Variables}

The independent variables in this study included: 1) respondents' demographic characteristics; 2) economic characteristics of the respondents' households, and 3) the respondents' expectations. Respondents' demographic characteristics included age; race/ethnicity; gender; marital status; education, and employment status. Age was included as a continuous variable. Respondents' race/ethnicity included White (reference group), Black, Hispanic, and other (including Asian, American Indian/Alaska Native, and Native Hawaiian/Pacific Islander). Gender included male and female (reference group). Marital status included married and unmarried (reference group). Respondents' education level was grouped into four categories: high school diploma or below (reference group); some college; bachelor's degree, and graduate or professional degree. Employment status included self-employed (reference group) and employed by someone else.

Economic characteristics included total household annual income; total household assets; total household liabilities; homeownership; respondents' defined benefit plan ownership; respondents' job tenure; use of financial planners; comparison of respondents' current and normal income, and whether the household overspent. The distributions of total household annual income, total assets, and liabilities were skewed positively, and using a natural logarithm helped the variables fit the model better; therefore, income, assets, and liabilities were logtransformed. Homeownership, defined benefit plan ownership, use of financial planners, and overspending were coded 1 for yes and 0 for no (reference group). Job tenure included less than 
one year (reference group) and at least one year. Comparison of current and normal household income was categorized as current income more than normal income, about the same, and less than normal (reference group). In the second step, the total amount of retirement account balance was subtracted from total assets and the difference was included as an independent variable instead of total assets. This variable was also log-transformed due to its skewness.

Respondents' expectations included saving motives; expectation about future U.S. economy; expectation of receiving a transfer of assets in the future (e.g., inheritance); respondents' self-perceived risk tolerance, and self-perceived health condition. Saving motive was coded 1 if the respondent reported saving for retirement and 0 otherwise (reference group). Expectation about future U.S. economy was categorized as future economy better than, about the same, and worse than current economy (reference group). Expecting to receive a transfer of assets in the future, including a substantial inheritance, was coded 1 for yes, 0 for no (reference group). Respondents' self-perceived risk tolerance included no (reference group), average, and high (above average and substantial) risk tolerance. Respondents self-perceived health condition was defined as excellent, good, fair, or poor (reference group).

\section{Data Analyses}

The complexity of the SCF data arises from the sample design, multiple imputation of missing data, and issues related to confidentiality and disclosure. The sample consists of a standard, geographically-based random sample and a list sample that oversamples wealthy households. The oversampling procedure provides more precise wealth estimates (especially for assets held rarely) and a method to correct for the higher rate of non-responses among wealthy households. This study used weights recommended by the Federal Reserve in the descriptive analysis to combine information from the two samples and determine estimates for the full 
population. To address the issue of missing data in the survey responses, the SCF incorporates five estimates that allow an estimate of the uncertainty attributable to this type of nonresponse (Ackerman, Fries, \& Windle, 2012). In the multivariate analysis, this study used the "repeatedimputation inference" method (Kennickell \& Woodburn, 1999) to include all five estimates, and the 999 bootstrap replicate weights provided by the SCF to compute estimates of sampling variance that address the confidentiality and disclosure concerns.

Retirement saving consists of two steps: 1) whether to own a retirement account, and 2) how much to save in it. Since whether to have a retirement account is a choice and those who do not have an account would have a zero balance, which introduces a potential sample selection bias for the second step. This study adopted Heckman's (1979) two-step estimation to correct for the potential sample selection bias. In the first step, the individual decides whether to own a retirement account:

$$
y_{1 i}=\beta_{10}+\beta_{1 i} x_{1 i}+\varepsilon_{1 i}
$$

where $y_{1 i}$ denotes ownership of retirement accounts (IRAs, DC plans, or both) and $x_{1 i}$ denotes the vector of factors that contribute to the decision to own retirement accounts. We adopted a Probit model to analyze factors that affect the likelihood of having a retirement account. In the second step, the individual decides how much to save in the retirement account:

$$
y_{2 i}=\beta_{20}+\beta_{2 i} x_{2 i}+\lambda+\varepsilon_{2 i}
$$

where $y_{2 i}$ denotes the amount of savings in the retirement accounts owned (log transformed), $x_{2 i}$ denotes the vector of factors that contribute to the amount of retirement savings, and $\lambda$ denotes the inverse Mills ratio. We used an ordinary least squares (OLS) model to estimate factors that affect the balance in the retirement accounts. By considering the potential selection bias, the inverse Mills ratio $(\lambda)$ was calculated in the first step and included in the second step. To 
improve the selection equation, an exclusionary variable that compared respondents' current and normal income was employed in this step.

\section{Results}

\section{Sample Characteristics by Retirement Account Ownership}

Table 1 reports Millennial respondents' characteristics by their retirement account ownership. More than a third (37.2\%) had at least one retirement account (IRA, DC plan, or both). Respondents who had retirement accounts were about two years older than on average than those who did not have any retirement account (average ages of 28.8 and 26.7, respectively). A higher percentage of White respondents (41.3\%) had retirement accounts than Black (34\%) and Hispanic (23.7\%) respondents. However, $61.7 \%$ of respondents of other races owned a retirement account. A higher percentage of male (40.6\%) and married (43.7\%) respondents had a retirement account than female (35.8\%) and unmarried respondents $(32.5 \%)$, and the percentage of retirement account ownership was higher for more educated respondents. For example, $65.2 \%$ of graduate or professional degree holders had a retirement account, while only $18.9 \%$ of respondents with a high school diploma or less did. The overwhelming majority $(93.4 \%)$ of respondents were employed by someone else, and their rate of retirement account ownership was more than twice $(39.8 \%)$ that of self-employed respondents $(17.6 \%)$.

Respondents with higher incomes also had a higher percentage of retirement accounts. For example, $11.3 \%$ of those with an income less than $\$ 16,000$ had retirement accounts, while $66.5 \%$ of those with an income equal to or greater than $\$ 60,000$ had such accounts. The relationship between retirement account ownership and household assets and liabilities followed the same pattern. The retirement account ownership rate was higher for respondents who owned 
a home, had a DB plan, consulted with a financial planner when making saving and investment decisions, had job tenure longer than 1 year, and did not overspend.

Approximately half $(50.1 \%)$ of respondents expected the U.S. economy to be better in the future, while the remainder expected it to be about the same $(16.8 \%)$, or worse $(33.1 \%)$. Approximately two-fifths of those who expected the economy to be better $(40.0 \%)$ or worse $(40.3 \%)$ had a retirement account. Respondents who expected to receive a substantial asset transfer, such as an inheritance, had a higher (40.9\%) rate of retirement account ownership than those who did not have such an expectation (37.6\%). Respondents who had a motive to save for retirement, had a higher level of risk tolerance, and were in better health also had a higher rate of retirement account ownership.

\section{Sample Characteristics by Retirement Account Balance}

Table 2 presents a descriptive analysis of Millennial respondents' retirement account balances. Overall, the distribution of retirement saving amounts was skewed to the right, with a mean of $\$ 21,333$ and median of $\$ 8,050$. Individuals of other races/ethnicities saved the greatest amount $(\$ 28,797)$. Males accounted for $55.1 \%$ of the sample with positive retirement savings and saved more than twice $(\$ 27,595)$ the average amount females saved $(\$ 13,656)$. On average, married individuals saved more $(\$ 26,651)$ than unmarried individuals $(\$ 14,264)$. Self-employed individuals accounted for only $3.0 \%$ of the sample with positive retirement savings. However, they saved an average of more than four times $(\$ 77,531)$ as much as those who worked for someone else $(\$ 18,499)$.

Respondents with a higher household income had a greater amount saved in their retirement accounts. For example, respondents with a household income of $\$ 60,000$ or higher saved an average of $\$ 32,942$, while those with a household income less than $\$ 16,000$ saved 
$\$ 4,553$. The distribution of retirement savings by household assets followed the same pattern. Millennials with less than $\$ 190$ in total liabilities saved the greatest amount in their retirement accounts $(\$ 34,157)$.

Respondents who were homeowners $(\$ 27,571)$; had a DB plan $(\$ 22,010)$; used a financial planner $(\$ 36,953)$; had worked for the current employer for at least a year $(\$ 23,108)$; received a normal income $(\$ 23,224)$, and did not overspend $(\$ 22,402)$ had greater average retirement savings than renters $(\$ 16,995)$; had no DB plan $(\$ 21,260)$; did not use financial planners $(\$ 18,513)$; had worked for the current employer for less than a year $(\$ 5,380)$; received an income lower than normal $(\$ 11,913)$, and overspent $(\$ 9,832)$. Respondents who had a higher average retirement savings also included those who had a retirement saving motive; expected the economy to be better in the future; did not expect to receive large asset transfers; had a high level of risk tolerance, and were in good health.

\section{Multivariate Analyses of Retirement Account Ownership and Balance}

Step 1: Results from Probit Analysis - Retirement Account Ownership

Results from multivariate analyses are reported in Table 3. Results from Step 1 are marginal effects and results from Step 2 are coefficients. Consistent with prior literature (Bassett et al., 1998; Hira et al., 2009; Knoll et al., 2012), older Millennials had a higher probability of having a retirement account than their younger counterparts. Each year increase in age increased the probability of having a retirement account by $15.5 \%$. Millennials with a graduate or professional degree had a $24.5 \%$ greater probability of owning a retirement account than those with a high school diploma or less. This is consistent with results from previous research (Yuh et al., 1996; Carney et al., 2001; Lusardi et al., 2007; Hira et al., 2009). Also consistent with prior 
research (Hire et al., 2009), those who worked for someone else had a $29.4 \%$ greater probability of owning a retirement account than self-employed respondents.

A positive relationship was found between total household assets and retirement account ownership, which was consistent with Smith, Finke and Huston's (2012) findings. A one unit increase in $\log$ (assets), which is a $172 \%(\mathrm{e}-1=172 \%)$ change in total household assets, increased the probability of having a retirement account by $9.1 \%$. Homeownership was negatively related to retirement account ownership. Compared with renters, homeowners were $14.1 \%$ less likely to have a retirement account. Probability of having a retirement account was $9.9 \%$ higher for those using financial planners when making saving and investment decisions and $8.6 \%$ lower for those who overspent in the past year. Compared to those who did not have a retirement saving motive, those who did were $7.4 \%$ more likely to have retirement accounts.

Step 2: Results from OLS Analysis - Retirement Account Balance

The last column in Table 3 reports OLS analysis results of the natural log of the total balance of retirement accounts for those who had at least one retirement account. One year increase in age increased the retirement account balance by $12.5 \%\left(e^{0.118}-1\right)$. Retirement account balance was $52.9 \%$ lower for Black respondents than White respondents. Similarly, being married, having a graduate or professional degree, and working for someone else negatively affected the amount saved in retirement accounts. One percentage increase in total household income increased the retirement account balance by $0.06 \%$. Every percent increase in total household assets other than retirement account assets and total household liabilities decreased the retirement account balance by $0.44 \%$ and $0.11 \%$, respectively. Homeownership, using financial planners, job tenure, having a retirement savings motive, and having a good health positively contributed to the total balance in Millennial respondents' retirement accounts. 


\section{Discussion and Implications}

This paper used data from the 2013 SCF to examine the state of Millennials' retirement savings, including retirement account ownership and balance. Multivariate regression analyses indicated that some factors that affected other generations also affected Millennials in the same way. In summary, age; education; total household assets; using financial planners; and having a retirement saving motive were significantly and positively related to Millennials' retirement account ownership, while self-employment, homeownership and overspending had negative effects on retirement account ownership in this generation. Age, self-employment, total household income, home ownership, using financial planners, job tenure, having a retirement saving motive, and good health had a positive effect on the dollar amount saved in accounts earmarked for retirement. Being Black, being married, having an advanced degree, total households assets other than retirement assets, and total household liabilities negatively contributed to retirement account balance.

It is worrisome that only $37.2 \%$ of working Millennials had a retirement account. Race and marital status did not affect retirement account ownership. However, among those who do have an account, Blacks saved significantly less than Whites after controlling for other variables. Future research should explore whether this difference in retirement savings was due to race in and of itself of whether other factors mediated this relationship. Married couples had a significant less amount saved than their unmarried counterparts. One possible reason may be that married couples have different types of expenses that affected their retirement savings. Future research may direct attention to retirement adequacy of married couples. It is interesting to note that compared to respondents with a high school diploma or below, advanced-degree holders were more likely to have a retirement account but saved a smaller amount in the account even 
after holding current job tenure. It is likely that advanced-degree holders are more likely than less-educated respondents to hold a job that sponsor a retirement plan. It is also plausible that less-educated respondents change jobs more often; so holding current job tenure constant, they have saved more from previous employment. It is also interesting that "other" race had the greatest portion of retirement account ownership but this group did not differ from Whites in terms of retirement account ownership or balance after controlling other variables. In the public dataset, this group include Asians and several other racial/ethnic groups other than Whites, Blacks, and Hispanics. Individuals in this group come from many different cultures. Treating them as a homogeneous group is problematic and does not generate meaningful results. Many previous articles excluded this group from analysis for this reason. However, given our relatively small sample size, excluding them would further restrict our sample size. This is the limitation of this study.

Among self-employed individuals, only $17.6 \%$ had a retirement account of any kind. It is understandable that because of its cost and complexity, it may be burdensome to have a DC plan. On the other hand, not having an IRA at minimum will likely have a negative effect on retirement security. Self-employed individuals may perceive that their businesses are their retirement plan (Coughlin, 2017). Monetizing a small business for retirement, however, may not be easy or even practical. Experts have projected that only 20-30\% of the businesses on the market will sell successfully (Biery, 2017). Self-employed individuals who did have at least one retirement account saved considerably more than those who worked for someone else. Because self-employed individuals hold a riskier job, it is plausible that those who do have retirement accounts recognized this nature of their job so they saved more to buffer this job uncertainty. 
Total household assets other than retirement account assets and total household liabilities negatively affected retirement account balance. Millennials with a higher balance in these assets and liabilities had less money to save for their retirement. Homeowners were less likely to own retirement accounts; however, among those who did have such accounts, homeowners saved significantly more. It is likely that some homeowners treat part of their home equity as their retirement so they are less likely to have retirement accounts. However, among those who have retirement accounts, some renters are saving for the down payment for a home so they have less money available to save for retirement.

Among Millennials who had no DB plan, 62.4\% also had neither an IRA nor DC plan. Historically, DB plans have provided additional retirement resources to previous generations, but only $8.9 \%$ of working Millennials have one. As a result, most Millennials who do not have a DB plan will have to shoulder more of the responsibility in preparing financially for retirement. Therefore, this generation should participate in DC plans and/or open an IRA to help fund their retirements. On the other hand, those without a DB plan who did have an IRA and/or a DC plan had a comparable amount saved in their retirement plans.

Millennials with no risk tolerance had the lowest proportion having a retirement account. This level of risk tolerance limits them to products that do not provide high returns. To compensate for the amount that does not come from investment earnings, these individuals not only should have retirement accounts but must contribute more to take advantage of the tax advantages of these accounts. It is interesting to note that neither retirement account ownership nor balance varied significantly by gender in the early stage of Millennials' careers. Future research should follow this generation and monitor whether factors related to their retirement savings behavior change over time and how they continue to prepare for retirement. 
This study is among the first to examine the financial well-being, specifically, the state of Millennials' retirement savings, of the biggest population in the United States. This study provided initial insights that can help financial planners and educators, as well as policymakers understand Millennials' current retirement savings behavior. The results suggested that financial education about saving for retirement is necessary. Beginning to save early in their careers would allow the power of compounding to work in favor of Millennial savers. Saving in an account that is earmarked for retirement purposes would not only help Millennials accumulate retirement wealth, but also would allow them to take advantage of tax preferences associated with retirement savings. Thus, strategic and disciplined savings would help Millennial workers achieve a financially comfortable life during retirement, and policies that encourage working Millennials to prepare for retirement should be considered. 


\section{References}

Ackerman, R. A., Fries, G., \& Windle, R. A. (2012). Changes in US family finances from 2007 to 2010: Evidence from the Survey of Consumer Finances. Federal Reserve Bulletin, 100, $1-80$.

Bajtelsmit, V. L., Bernasek, A., \& Jianakoplos, N. A. (1999). Gender differences in defined contribution pension decisions. Financial Services Review, 8(1), 1-10.

Bams, D., Schotman, P., \& Tyagi, M. (2016). Pension fund asset allocation in low interest rate environment (Discussion Paper No. 03/2016-017). Retrieved from https://faculty.mccombs.utexas.edu/keith.brown/AFPMaterial/PF AsstAllocate WP3.21.16.pdf

Bassett, W. F., Fleming, M. J., \& Rodrigues, A. P. (1998). How workers use 401(k) plans: The participation, contribution, and withdrawal decisions. National Tax Journal, 51(2), 263289.

Biery, M. E. (2017, February 5). Study shows why many business owners can't sell when they want to. Retrieved from https://www.forbes.com/sites/sageworks/2017/02/05/these-8stats-show-why-many-business-owners-cant-sell-when-they-want-to/\#ea7a0544bd5a

Boivie, I. (2011). Who killed the private sector DB plan? National Institute on Retirement Security, Washington, DC. Retrieved from http://corpath.org/wpcontent/uploads/2014/08/WhoKilledthePrivateDBPlan.pdf

Burke, J., Hung, A. A., \& Luoto, J. E. (2015). Automatic enrollment in retirement savings vehicles. (Working Paper No. 117). Santa Monica, CA: RAND Corporation. Retrieved 
from

https://pdfs.semanticscholar.org/8830/5ed23647b9fee56779e64c55405d5f921d9c.pdf

Carney, S., \& Gale, W. G. (2001). Asset accumulation in low-income households. In T. M. Shapiro \& E. N. Wolff (Eds.), Assets for the poor: The benefits of spreading asset ownership (pp. 165-205). New York: Russell Sage Foundation.

Clark, R. L., d'Ambrosio, M. B., McDermed, A. A., \& Sawant, K. (2006). Retirement plans and saving decisions: The role of information and education. Journal of Pension Economics \& Finance, 5(1), 45-67.

Clark, R. L., d'Ambrosio, M. B., McDermed, A. A., and Sawant, K. (2003). Financial Education and Retirement Savings. (TIAA-CREF Institute Working Paper 11-020103). Washington, DC: TIAA-CREF Institute. Retrieved from https://www.researchgate.net/profile/Robert Clark14/publication/5036664 Financial ed ucation and retirement savings/links/0c960521c89df7fd2f000000.pdf

Copeland, C. (2015). Individual Retirement Account Balances, Contributions, and Rollovers, 2013 with Longitudinal Results 2010-2013: The EBRI IRA Database. Retrieved from https://www.ebri.org/pdf/briefspdf/EBRI IB 414.May15.IRAs.pdf

Coughlin, J. (2017, September 16). Small business owners are retiring, and Millennials may not fill the gap on America's main street. Retrieved from https://www.forbes.com/sites/josephcoughlin/2017/09/16/small-business-owners-areretiring-why-millennials-may-not-fill-the-gap-on-americas-main-street/\#fa6c2c25d489

Demirgüç-Kunt, A., Klapper, L., Panos, G.A. (2016). Saving for old age. (Policy Research Working Paper No. 7693). World Bank Group. Retrieved from https://papers.ssrn.com/sol3/papers.cfm?abstract $\mathrm{id}=2811340$ 
DeVaney, S. A., \& Chiremba, S. T. (2005). Comparing the retirement savings of the baby boomers and other cohorts. Compensation and working conditions online.

Retrieved from https:/www.bls.gov/opub/mlr/cwc/comparing-the-retirement-savings-ofthe-baby-boomers-and-other-cohorts.pdf

DeVaney, S. A., \& Zhang, T. C. (2001). A cohort analysis of the amount in defined contribution and individual retirement accounts. Journal of Financial Counseling and Planning, 12(1), 89-102.

Farrell, J., \& Shoag, D. (2016). Asset management in public DB and non-DB Pension Plans. Journal of Pension Economics \& Finance, 15(4), 379-406.

Fidelity Investments. (2016). 2016 Fidelity Investments Millennial Money Study. Retrieved from https://www.fidelity.com/bin-public/060 www fidelity com/documents/pr/millennial$\underline{\text { money-fact-sheet.pdf }}$

Fry, R. (2016). Millennials overtake Baby Boomers as America’s largest generation. Pew Research Center. Retrieved from http://www.pewresearch.org/fact$\underline{\operatorname{tank} / 2016 / 04 / 25 / \text { millennials-overtake-baby-boomers/ }}$

Geisel, J. (2016). Fortune 500 continues to shed pension plans. Business Insurance. Retrieved from https://www.businessinsurance.com/article/20160222/NEWS03/160229986

Genay, H., \& Podjasek, R. (2014). What is the impact of a low interest rate environment on bank profitability? Chicago Fed Letter, 324 (July), Federal Reserve Bank of Chicago. Retrieved from https://ideas.repec.org/a/fip/fedhle/00009.html

Ghilarducci, T., Saad-Lessler, J., Bahn, K. (2015). Are U.S. workers ready for retirement?: Trends in plan sponsorship, participation, and preparedness. Journal of Pension Benefits, Ferenczy Benefits Law Center, Winter, 25-39. 
Heckman, J. J. (1979). Sample selection bias as a specification error. Econometrica, 47(1), 153161.

Hershey, D. A., Jacobs-Lawson, J. M., McArdle, J. J., \& Hamagami, F. (2007). Psychological foundations of financial planning for retirement. Journal of Adult Development, 14(1-2), 26-36.

Hinz, R. P., McCarthy, D. D., \& Turner, J. A. (1997). Are women conservative investors? Gender differences in participant-directed pension investments. In M. S. Gordon, O. S. Mitchell, \& M. M. Twinney (Eds.), Positioning pensions for the twenty-first century (pp. 91-103). Philadelphia, PA: University of Pennsylvania Press.

Hira, T. K., Rock, W. L., \& Loibl, C. (2009). Determinants of retirement planning behaviour and differences by age. International Journal of Consumer Studies, 33(3), 293-301.

Holden, K. C., \& Fontes, A. (2009). Economic security in retirement: How changes in employment and marriage have altered retirement-related economic risks for women. Journal of Women, Politics \& Policy, 30(2-3), 173-197.

Holden, S., \& VanDerhei, J. (2003). 401(k) plan asset allocation, account balances, and loan activity in 2001. Investment Company Institute Perspective 9(2), 1-19.

Honig, M., \& Dushi, I. (2010). Participation and contribution in tax-deferred retirement accounts: Evidence from Social Security records. (Michigan Retirement Research Center Working Paper No. 2009-216). Ann Arbor, MI: University of Michigan. Retrieved from https://www.cdc.gov/nchs/data/hus/hus16.pdf\#015

Jacobs-Lawson, J. M., \& Hershey, D. A. (2005). Influence of future time perspective, financial knowledge, and financial risk tolerance on retirement saving behaviors. Financial Services Review, 14(4), 331-344. 
Jeszeck, C. A., Collins, M. J., Glickman, M., Hoffrey, L., \& Grover, S. (2015). Retirement security: Most households approaching retirement have low savings. United States Government Accountability Office. Retrieved from https://ssrn.com/abstract=2761200

Joo, S., \& Grable, J. E. (2005). Employee education and the likelihood of having a retirement savings program. Journal of Financial Counseling and Planning, 16(1), 37-49.

Kennickell, A. B., \& Woodburn, R. L. (1999). Consistent weight design for the 1989, 1992 and 1995 SCFs, and the distribution of wealth. Review of Income and Wealth, 45(2), 193-215.

Knoll, M. A., Tamborini, C. R., \& Whitman, K. (2012). I do...want to save: Marriage and retirement savings in young households. Journal of Marriage and Family, 74(1), 86-100. doi: $10.1111 / j .1741-3737.2011 .00877 . x$

Lusardi, A. (2003). Planning and saving for retirement. Working paper. Dartmouth College. Retrieved from https://pdfs.semanticscholar.org/fd92/446c257ae6314481264bd2252d53c9d47e06.pdf

Lusardi, A., \& Mitchell, O. S. (2007). Baby boomer retirement security: The roles of planning, financial literacy, and housing wealth. Journal of Monetary Economics, 54(1), 205-224.

Munnell, A. H., Webb, A., \& Hou, W. (2014). How much should people save? Center for Retirement Research at Boston College. (Issue Brief, No. 14-11). Chestnut Hill, MA: Center for Retirement Research at Boston College.

National Center for Health Statistics. (2017). Health, United States, 2016: With chartbook on long-term trends in health. Hyattsville, MD. Retrieved from https://www.cdc.gov/nchs/data/hus/hus16.pdf - 015

Neelakantan, U., \& Chang, Y. (2010). Gender differences in wealth at retirement. The American Economic Review, 100(2), 362-367. 
Oakley, D., \& Kenneally, K. (2013). Pensions and retirement security 2013. Washington, DC: National Institute on Retirement Security. Retrieved from http://www.nirsonline.org/storage/nirs/documents/2013 Opinion

$\underline{\text { Study/final 2013restricted opinion research.pdf }}$

Pentegra Retirement Services. (2017). Pentegra Millennial Saving Survey. Retrieved from http://www.pentegra.com/wp-content/uploads/2016/12/Pentegra-Millennial-SavingsSurvey-Report.pdf

Poterba, J. M. (2014). Retirement security in an aging population. The American Economic Review, 104(5), 1-30.

Poterba, J. M., \& Wise, D. A. (1998). Individual financial decisions in retirement saving plans and the provision of resources for retirement. In M. Feldstein (Ed.), Privatizing social security (pp. 363-401). Chicago, IL: University of Chicago Press.

Poterba, J., Rauh, J., Venti, S., \& Wise, D. (2006). Lifecycle asset allocation strategies and the distribution of 401(k) retirement wealth (NBER Working Paper No. 11974). National Bureau of Economic Research. Retrieved from http://www.piketty.pse.ens.fr/files/Poterbaetal2006.pdf

Rhee, N. (2013). Race and retirement insecurity in the United States. Washington, DC: National Institute on Retirement Security. Retrieved from https://www.giaging.org/documents/NIRS_Report_12-10-13.pdf

Smith, H., Finke, M., \& Huston, S. (2012). The influence of financial sophistication and financial planners on Roth IRA ownership. Journal of Financial Service Professionals, 66(6), 69-81. 
Social Security Board of Trustees. (2017). The 2017 annual report of the Board of Trustees of the federal old-age and survivors insurance and federal disability insurance trust funds. Retrieved from https://www.ssa.gov/oact/tr/2017/tr2017.pdf.

Sunden, A. E., \& Surette, B. J. (1998). Gender differences in the allocation of assets in retirement savings plans. The American Economic Review, 88(2), 207-211.

U.S. Census Bureau. (2015). Millennials outnumber Baby Boomers and are far more diverse, census bureau reports. Retrieved from https://www.census.gov/newsroom/pressreleases/2015/cb15-113.html

U.S. Department of Labor. (2016). Private pension plan bulletin historical tables and graphs 1975-2014. Retrieved from https://www.dol.gov/sites/default/files/ebsa/researchers/statistics/retirementbulletins/private-pension-plan-bulletin-historical-tables-and-graphs.pdf

Van Rooij, M., Lusardi, A., \& Alessie, R. (2011). Financial literacy and stock market participation. Journal of Financial Economics, 101(2), 449-472.

VanDerhei, J., Holden, S., Alonso, L., \& Copeland, C. (2008). 401(k) plan asset allocation, account balances, and loan activity in 2007. (Issue Brief, No. 324). Washington DC: Employee Benefits Research Institute. Retrieved from https://papers.ssrn.com/sol3/papers.cfm?abstract id=1318375

Wells Fargo. (2016). 2016 Wells Fargo Millennial Study. Retrieved from https://www08.wellsfargomedia.com/assets/pdf/commercial/retirement-employeebenefits/perspectives/2016-millennial-retirement-study.pdf

Xiao, J. J. (1997). Saving motives and 401 (k) contributions. Journal of Financial Counseling and Planning, 8(2), 65-74. 
Xiao, J. J., \& Noring, F. E. (1994). Perceived saving motives and hierarchical financial needs. Financial Counseling and Planning, 5(1), 25-44.

Yao, R., Ying, J., \& Micheas, L. (2013). Determinants of defined contribution plan deferral. Family and Consumer Sciences Research Journal, 42(1), 55-76.

Yilmazer, T., \& Scharff, R. L. (2014). Precautionary savings against health risks: Evidence from the Health and Retirement Study. Research on Aging, 36(2), 180-206.

Yuh, Y., \& DeVaney, S. A. (1996). Determinants of couples' defined contribution retirement funds. Journal of Financial Counseling and Planning, 7, 31. 
Table 1 Sample Characteristics by Retirement Account Ownership

\begin{tabular}{|c|c|c|c|}
\hline & & count & \\
\hline & Yes & No & Total \\
\hline Overall Percentage & 37.2 & 62.8 & 100.0 \\
\hline Respondent's Demographic Charact & & & \\
\hline Age (mean) & 28.8 & 26.7 & 100.0 \\
\hline Race/ethnicity & & & \\
\hline White ${ }^{* * *}$ & 41.3 & 58.7 & 63.9 \\
\hline Black*** & 34.0 & 66.0 & 15.8 \\
\hline Hispanic $* * *$ & 23.7 & 76.3 & 15.7 \\
\hline Other*** & 61.7 & 38.3 & 4.6 \\
\hline Gender & & & \\
\hline Male** & 40.6 & 59.4 & 52.0 \\
\hline Female** & 35.8 & 64.2 & 48.0 \\
\hline Marital status & & & \\
\hline Unmarried ${ }^{* * *}$ & 32.5 & 67.5 & 48.2 \\
\hline Married ${ }^{* * *}$ & 43.7 & 56.3 & 51.8 \\
\hline Education & & & \\
\hline High school diploma or below $* * *$ & 18.9 & 81.1 & 30.6 \\
\hline Some college $\mathrm{e}^{* * *}$ & 34.3 & 65.7 & 32.8 \\
\hline Bachelor's degree ${ }^{* * *}$ & 54.7 & 45.3 & 24.7 \\
\hline Graduate or professional degree $* * *$ & 65.2 & 34.8 & 11.9 \\
\hline Employment status & & & \\
\hline Work for someone ${ }^{* * *}$ & 39.8 & 60.2 & 93.4 \\
\hline Self-employed $* * *$ & 17.6 & 82.4 & 6.6 \\
\hline Household's Economic Status & & & \\
\hline Total household income & & & \\
\hline$<\$ 16,000 * * *$ & 11.3 & 88.7 & 23.5 \\
\hline$\$ 16,000-\$ 32,999^{* * *}$ & 24.9 & 75.1 & 23.6 \\
\hline$\$ 33,000-\$ 59,999 * * *$ & 45.5 & 54.5 & 25.7 \\
\hline$\geq \$ 60,000^{* * *}$ & 66.5 & 33.5 & 27.1 \\
\hline Total household assets & & & \\
\hline$<\$ 7,500^{* * *}$ & 11.2 & 88.9 & 22.5 \\
\hline$\$ 7,500-\$ 21,499 * * *$ & 26.9 & 73.1 & 23.0 \\
\hline$\$ 21,500-\$ 125,999^{* * *}$ & 44.8 & 55.2 & 25.1 \\
\hline$\geq \$ 126,000 * * *$ & 62.6 & 37.4 & 29.3 \\
\hline Total household liabilities & & & \\
\hline$<\$ 190 * * *$ & 21.6 & 78.4 & 23.0 \\
\hline$\$ 190-\$ 14,999 * * *$ & 26.2 & 73.8 & 23.2 \\
\hline$\$ 15,000-\$ 77,789^{* * *}$ & 34.3 & 65.8 & 24.7 \\
\hline$\geq \$ 77,790 * * *$ & 63.7 & 36.3 & 29.1 \\
\hline Home ownership & & & \\
\hline Yes*** & 55.3 & 44.7 & 33.8 \\
\hline
\end{tabular}


No***

Have defined benefit plan(s)

Yes**

No**

Use financial planner

Yes***

No***

Job tenure

Less than 1 year***

At least 1 year***

Overspent

Yes***

No***

\section{Respondent's Expectations}

Have retirement as a saving motive

$$
\begin{aligned}
& \text { Yes*** } \\
& \text { No*** }
\end{aligned}
$$

Expectation of future U.S. economy

\section{Better***}

About the same***

Worse***

Expected to receive heritage

Yes

No

Risk tolerance level

No risk***

High***

Health condition

Excellent***

Good***

Fair/Poor***

NOTE: $* p<.05$; 2013 Survey of Consumer Finances; weighted result; original sample size $=782$; numbers in percentages 
Table 2 Sample Characteristics by Retirement Account Balance

\begin{tabular}{|c|c|c|c|}
\hline & $\begin{array}{c}\text { Weighted } \\
\text { Percentage }\end{array}$ & $\begin{array}{c}\text { Mean } \\
\text { Dollars }\end{array}$ & $\begin{array}{l}\text { Median } \\
\text { Dollars }\end{array}$ \\
\hline Overall & 100.0 & 21,333 & 8,050 \\
\hline \multicolumn{4}{|c|}{ Respondent's Demographic Characteristics } \\
\hline \multicolumn{4}{|c|}{ Race/ethnicity } \\
\hline White & 68.9 & 24,298 & 10,000 \\
\hline Black & 14.0 & 8,014 & 3,000 \\
\hline Hispanic & 9.7 & 13,033 & 6,600 \\
\hline Other & 7.4 & 28,797 & 11,000 \\
\hline \multicolumn{4}{|l|}{ Gender } \\
\hline Male & 55.1 & 27,595 & 10,000 \\
\hline Female & 44.9 & 13,656 & 5,920 \\
\hline \multicolumn{4}{|l|}{ Marital status } \\
\hline Unmarried & 40.9 & 14,264 & 5,440 \\
\hline Married & 59.1 & 26,651 & 10,000 \\
\hline \multicolumn{4}{|l|}{ Education } \\
\hline High school diploma or below & 15.1 & 24,619 & 7,450 \\
\hline Some college & 29.4 & 15,145 & 5,000 \\
\hline Bachelor's degree & 35.3 & 24,530 & 8,300 \\
\hline Graduate or professional degree & 20.3 & 21,819 & 12,000 \\
\hline \multicolumn{4}{|l|}{ Employment status } \\
\hline Work for someone & 97.0 & 18,499 & 8,000 \\
\hline Self-employed & 3.0 & 77,531 & 19,000 \\
\hline \multicolumn{4}{|l|}{ Household's Economic Status } \\
\hline \multicolumn{4}{|l|}{ Total household income } \\
\hline$<\$ 16,000$ & 6.9 & 4,553 & 1,450 \\
\hline$\$ 16,000-\$ 32,999$ & 15.3 & 5,382 & 2,300 \\
\hline$\$ 33,000-\$ 59,999$ & 30.6 & 17,325 & 7,250 \\
\hline$\geq \$ 60,000$ & 47.1 & 32,942 & 15,000 \\
\hline \multicolumn{4}{|c|}{ Total household assets (excluding retirement account assets) } \\
\hline$<\$ 7,250$ & 7.7 & 4,106 & 2,300 \\
\hline$\$ 7,250-\$ 20,499$ & 15.6 & 7,684 & 3,000 \\
\hline$\$ 20,500-\$ 125,800$ & 28.3 & 15,949 & 6,800 \\
\hline$\geq \$ 125,801$ & 48.4 & 34,556 & 19,000 \\
\hline \multicolumn{4}{|l|}{ Total household liabilities } \\
\hline$<\$ 190$ & 13.0 & 34,157 & 10,000 \\
\hline$\$ 190-\$ 14,999$ & 15.9 & 10,457 & 3,500 \\
\hline$\$ 15,000-\$ 77,789$ & 22.1 & 16,716 & 5,000 \\
\hline$\geq \$ 77,790$ & 49.0 & 23,807 & 13,000 \\
\hline \multicolumn{4}{|l|}{ Home ownership } \\
\hline Yes & 48.8 & 27,571 & 13,000 \\
\hline No & 51.2 & 16,995 & 5,000 \\
\hline
\end{tabular}

Have defined benefit plan(s) 


\begin{tabular}{|c|c|c|c|}
\hline Yes & 89.3 & 22,010 & 10,000 \\
\hline No & 10.7 & 21,260 & 8,000 \\
\hline \multicolumn{4}{|c|}{ Use financial planner } \\
\hline Yes & 14.9 & 36,953 & 8,800 \\
\hline No & 85.1 & 18,513 & 8,000 \\
\hline \multicolumn{4}{|l|}{ Job tenure } \\
\hline Less than 1 year & 9.7 & 5,380 & 1,000 \\
\hline At least 1 year & 90.3 & 23,108 & 10,000 \\
\hline \multicolumn{4}{|c|}{ Current income vs. normal income } \\
\hline Higher & 7.9 & 20,841 & 10,000 \\
\hline About the same & 77.5 & 23,224 & 8,500 \\
\hline Lower & 14.6 & 11,913 & 2,900 \\
\hline \multicolumn{4}{|l|}{ Overspent } \\
\hline Yes & 8.4 & 9,832 & 1,650 \\
\hline No & 91.6 & 22,402 & 9,000 \\
\hline \multicolumn{4}{|c|}{ Respondent's Expectations } \\
\hline \multicolumn{4}{|c|}{ Have retirement as a saving motive } \\
\hline Yes & 32.9 & 23,839 & 12,000 \\
\hline No & 67.1 & 20,122 & 7,700 \\
\hline \multicolumn{4}{|c|}{ Expectation of future U.S. economy } \\
\hline Better & 52.4 & 23,577 & 9,900 \\
\hline About the same & 34.8 & 18,695 & 8,100 \\
\hline Worse & 12.8 & 19,544 & 3,500 \\
\hline \multicolumn{4}{|c|}{ Expected to receive heritage } \\
\hline Yes & 21.8 & 19,494 & 10,000 \\
\hline No & 78.2 & 21,832 & 8,000 \\
\hline \multicolumn{4}{|l|}{ Risk tolerance level } \\
\hline No risk & 25.4 & 11,520 & 2,500 \\
\hline Average & 41.1 & 19,442 & 10,000 \\
\hline High & 33.5 & 31,068 & 11,000 \\
\hline \multicolumn{4}{|l|}{ Health condition } \\
\hline Excellent & 49.7 & 19,278 & 6,900 \\
\hline Good & 31.2 & 25,687 & 12,000 \\
\hline Fair/poor & 19.2 & 16,907 & 5,000 \\
\hline
\end{tabular}

NOTE: Analysis of the 2013 Survey of Consumer Finances; weighted result; original sample size $=291$. 
Table 3 Probit Analysis of Retirement Account Ownership and OLS analysis of Retirement Account Balance

\begin{tabular}{|c|c|c|}
\hline Variable & $\begin{array}{l}\text { Step 1: } \\
\text { Ownership } \\
\text { Marginal Effect }\end{array}$ & $\begin{array}{l}\text { Step 2: } \\
\text { Log(Balance) } \\
\text { Coefficients } \\
\end{array}$ \\
\hline Intercept & - & $24.543 * * *$ \\
\hline \multicolumn{3}{|l|}{ Respondent's Demographic Characteristics } \\
\hline Age & $0.155 * * *$ & $0.118 *$ \\
\hline \multicolumn{3}{|l|}{ Race/ethnicity (reference category = White) } \\
\hline Black & 0.056 & $-0.753 * *$ \\
\hline Hispanic & -0.077 & 0.543 \\
\hline Other & 0.036 & 0.251 \\
\hline Gender (reference category $=$ female $)$ & -0.031 & -0.061 \\
\hline Marital status (reference category = unmarried) & 0.020 & $-0.290 *$ \\
\hline \multicolumn{3}{|l|}{ Education (reference category $=$ high school diploma or below) } \\
\hline Some college & 0.122 & -0.693 \\
\hline Bachelor's degree & 0.110 & -0.303 \\
\hline Graduate or professional degree & $0.245 * *$ & $-1.879 *$ \\
\hline Employment status (reference category = self-employed) & $0.294 * * *$ & $-4.067 * * *$ \\
\hline \multicolumn{3}{|l|}{ Household's Economic Status } \\
\hline Log (total household income) & 0.003 & $0.060^{*}$ \\
\hline Log (total household assets) & $0.091 * * *$ & - \\
\hline Log (total household assets excluding retirement account assets) & - & $-0.448 *$ \\
\hline Log (total household liabilities) & 0.005 & $-0.112^{* * *}$ \\
\hline Home ownership & $-0.141 * * *$ & $1.242 * * *$ \\
\hline Have defined benefit plan(s) & -0.095 & 0.775 \\
\hline Use financial planner & $0.099 *$ & $1.223 * * *$ \\
\hline Job tenure (reference category = less than 1 year) & 0.073 & $0.646^{* *}$ \\
\hline \multicolumn{3}{|l|}{ Current income vs. normal income (reference category $=$ lower) } \\
\hline Higher & - & 0.301 \\
\hline About the same & - & 0.511 \\
\hline Overspent & $-0.086^{*}$ & 0.823 \\
\hline \multicolumn{3}{|l|}{ Respondent's Expectations } \\
\hline Saving for retirement & $0.074 *$ & $0.604 * *$ \\
\hline \multicolumn{3}{|l|}{ Expectation of future U.S. economy (reference category = worse) } \\
\hline Better & 0.017 & 0.177 \\
\hline About the same & 0.047 & -0.159 \\
\hline Expected to receive heritage & -0.004 & 0.357 \\
\hline \multicolumn{3}{|l|}{ Risk tolerance level (reference category = no risk) } \\
\hline Average & 0.061 & -0.306 \\
\hline High & -0.027 & 0.412 \\
\hline \multicolumn{3}{|l|}{ Health condition (reference category = fair or poor health) } \\
\hline Excellent & 0.007 & 0.346 \\
\hline Good & -0.023 & $0.557^{*}$ \\
\hline
\end{tabular}


Lambda

NOTE: $* p<.05 ; * * p<.01 ; * * * p<.001$. Analysis of the 2013 Survey of Consumer Finances. 